will be detected, that the new test has a similar probability of success. The distribution of medians and individual risk estimates in our study suggests that there is a high probability that women older than 35 with affected pregnancies would be offered screening. This was also found in a recent study by Mancini $e t a l .^{13}$ Furthermore, as the median calculated risk for women over 40 is higher than 1:350 more than half of those women would be offered screening. As only $0.6 \%$ of births are in women over 40 offering amniocentesis and karyotyping to all women in this age group would increase the number of pregnancies requiring screening by only about $0.3 \%$. This would also address the problem that allocating access to karyotype determination on the basis of risk of Down's syndrome alone ignores the possibility of other chromosomal abnormalities in older pregnant women. Other chromosomal disorders are rarer than trisomy 21 and because the risk is less strongly age dependent are less effectively screened by age alone.

The number of younger women requesting amniocentesis because of anxiety might be expected to fall when counselling can include the discussion of a method of individual risk assessment with a high expectation of success in detecting Down's syndrome. This should compensate the increase in screening generated by offering karyotype screening to women aged over 40 without biochemical evidence of their pregnancy being at high risk of Down's syndrome.

This study was supported by Tayside Health Board. We thank Valerie Berthoud, Lyndsey Cuthill, and Shirley Moore for technical help; Sharon Mudie and Lesley Nicol for retrieval of cytogenetic and ultrasonic data; and Margaret Henderson for secretarial help. We also thank the Department of Biochemical Medicine for providing stored serum samples.

1 Cucke HS, Wald NJ, Thompson SG. Esimating a womas risk of having a pregnancy associated with Down's svndrome using her age and maternal serum alpha-fetoprotein level. Brf Obstet (iynaecol 1987;94:387-402.

2 Norgaard-Pedersen B, Larsen SO, Arends J, Svenstrup B, Tabor A. Maternal serum markers in screening for Down syndrome. Clin Genet 1990;37:35-43.

3 Wald NJ, Cuckle HS, Densem JW, Nanchahal K, Canick JA, Haddow JE, et al. Maternal serum screening for Down's syndrome in early pregnancy. BMF 1988;297:883-7.

4 Merkatz IR, Nitowsky HM, Macri JN, Johnson WE. An association between low maternal serum $\alpha$ fetoprotein and fetal chromosome abnormality. $A m \mathcal{J}$ Obstet Gynecol 1984;148:886-94.

5 Bogart MH, Pandian MR, Jones OW. Abnormal maternal serum chorionic gonadotrophin levels in pregnancies with fetal chromosome abnormalities. Diagn 1987;7:623-30.

6 Canick JA, Knight GJ, Palomaki GE, Haddow JE, Cuckle HS, Wald NJ. Low second trimester maternal serum unconjugated oestriol in pregnancy with Down's syndrome. Br f Obstet Gynaecol 1988;95:330-3.

7 Stevenson JD, Chapman RS, Perry B, Logue FC. Evaluation and clinical application of a two site immunoradiometric assay for alpha-1-foetoprotein using readily available reagents. Ann Clin Biochem 1987;24:411-8.

8 Walker EM, Lewis M, Cooper W, Marnie M, Howie PW. Occult biochemical pregnancy: fact or fiction? Br f Obstet Gynaecol 1988;95:659-63.

9 Christie AD. Standards in ultrasound fetal biometry [PhD thesis]. Dundee University of Dundee, 1980.

10 Wald NJ, Cuckle HS. Biochemical detection of neural tube defects and Down's syndrome. In: Turnball AC, Chamberlain G, eds. Obstetrics. Edinburgh: Churchill Livingstone, 1989:269-89.

11 Suchy SF, Yeager MT. Down syndrome screening in women under 35 with maternal serum hCG. Obstet Gynecol 1990;76:20-4.

12 Macri JN, Kasturi RV, Krantz DA, Cook EJ, Moore ND, Young JA, et al. Maternal serum Down syndrome screening: free $\beta$ protein is a more effective marker than human chorionic gonadotropin. Am J Obstet Gynecol 1990;163: 1248-53.

13 Mancini G, Perona M, Dall'Amico D, Bollati C, Albano F, Mazzone R, et al. Screening for fetal Down's syndrome with maternal serum markers - an experience in Italy. Prenat Diagn 1991;11:245-52.

(Accepted 13 fune 1991)
Human Population

Laboratory, California

Public Health Foundation, Berkeley, California 94704-9980, United States

Nancy B Lazarus, MD, research scientist

Richard D Cohen, MA, biostatistician

Diing-Jen Leu, MPH,

research analyst

\section{Human Population}

Laboratory, California

Department of Health

Sciences, Berkeley,

California 94704-9980,

United States

George A Kaplan, PHD,

chief of laboratory

Correspondence and requests for reprints to: Dr Kaplan.

BMF 1991;303:553-6

Change in alcohol consumption and risk of death from all causes and from ischaemic heart disease//

Nancy B Lazarus, George A Kaplan, Richard D/Cohen, Diing-Jen/Leu

\section{Abstract}

Objective-To examine the association between alcohol consumption and mortality from all causes and from ischaemic heart disease with a focus on differentiating between long term abstainers and more recent non-drinkers.

Design-Cohort study of changes in alcohol consumption from 1965 to 1974 and mortality from al causes and ischaemic heart disease during 1974-84.

Setting-Population based study of adult residents of Alameda County, California.

Subjects -2225 women and 1845 men aged 35 and over in 1965.

Main outcome measures-Alcohol consumption in 1964 and 1974 and mortality from all causes and from ischaemic heart disease during 1974-84.

Results - There was a significantly higher risk of death from all causes and from ischaemic heart disease in women who gave up drinking between 1965 and 1974 than in women who continued to drink (relative risk $1 \cdot 72,95 \%$ confidence interval 1.11 to 2.66 , and $2.75,1.44$ to 5.23 , for all causes and ischaemic heart disease respectively). A significant increase in risk was not seen in men who gave up drinking $(1.32,0.87$ to 2.01 , and $0.95,0.41$ to $2 \cdot 20$, respectively). Among men, long term abstainers compared with drinkers were at increased risk of death from all causes and from ischaemic heart disease, though the associations were not significant $(1.40,0.98$ to 2.00 , and $1.40,0.76$ to 2.58 , for all causes and ischaemic heart disease respectively).

Conclusion-Some of the increased risk of death from all causes and from ischaemic heart disease associated with not drinking in women seems to be accounted for by higher risks among those who gave up drinking. Men who are long term abstainers may also be at an increased risk of death. The heterogeneity of the non-drinking group should be considered when comparisons are made with drinkers.

\section{Introduction}

Several studies have described a J-shaped association between intake of alcohol and risk of cardiovascular disease, with the lowest risk among light drinkers and higher risks among non-drinkers and heavy drinkers. ${ }^{1-8}$ The observation that non-drinkers have a higher incidence of cardiovascular disease than light drinkers has led to light drinking being characterised as "protective." This characterisation is not without biological plausibility given the observations of increased concentrations of high density lipoprotein cholesterol with increased alcohol consumption. ${ }^{34-11}$ Also, Meade et al have suggested that alcohol's antithrombotic effects may be responsible for this protective effect. ${ }^{12}$

There is, however, another possible explanation for the effect. Most analyses treat non-drinkers as a homogeneous group, but it is likely that non-drinkers constitute an extremely heterogeneous group consisting of life long abstainers and also former drinkers, who may have a higher risk of death. ${ }^{13.14 a}$ If these subgroups differ with respect to risk of cardiovascular 
disease then conclusions based on a comparison of nondrinkers with light drinkers might be misleading.

There is suggestive evidence from four other studies supporting the heterogeneity of the group of nondrinkers with respect to risk of coronary heart disease. In the Western Electric study former drinkers had a 2.4 times greater incidence of death from cardiovascular causes than lifetime non-drinkers. ${ }^{415}$ In the Honolulu heart study, in which the study group was characterised by a low level of alcohol consumption, former drinkers had a $28 \%$ higher incidence of coronary heart disease compared with lifetime nondrinkers. ${ }^{1-2}$ Even greater differences were found in the Tecumseh study. ${ }^{16}$ In the British regional heart study former drinkers when compared with teetotallers and current drinkers had higher prevalences of high blood pressure, angina, and electrocardiographic evidence of definite or possible myocardial infarction.

In our study we used data from the Alameda County study to evaluate the risk of death in the subgroups within non-drinkers. We examined the relation between changes in alcohol consumption over nine years (1965-74) and subsequent risk of death after 11 years (1974-84) in people aged 35 or more who participated in the Alameda County study in 1965 and in a follow up study in 1974 .

\section{Subjects and methods}

The data used in these analyses came from our laboratory's study of adult residents of Alameda County, California. The details of the study design and sampling method have been reported elsewhere. ${ }^{18}$ In 1965 a representative sample of 8023 non-institutionalised adults aged 20 or more ( 16 if ever married) were selected through a stratified random sample of Alameda County housing units. Of these, 6928 (86\%) completed an extensive questionnaire about their behavioural, social, and psychological characteristics as well as their health and disease status and functional disabilities.

In 1974 an attempt was made to recontact those who responded in 1965. Between 1965 and 1974, 693 $(10.0 \%)$ of the subjects died. Only $273(3.9 \%)$ were lost to follow up at nine years. Completed questionnaires were received from $4864(81 \cdot 6 \%)$ of the 5962 surviving subjects who were located. Alcohol scores were missing for 794 subjects who were aged 35 and over in 1974 , so the analyses reported here are based on 2225 women and 1845 men.

Between 1974 and 1984, 591 of the 4070 respondents died (291 women and 300 men). Mortality was ascertained for the 20 years from 1965 to 1984 by a computerised record linkage with the California Death Registry $^{18.21}$ to obtain the death certificates of those people who had died in California or outside the state with notification to California. Those not known to be dead were considered to be alive.
The underlying cause of death from death certificates was coded according to the eighth revision of the International Classification of Diseases.

The alcohol consumption scores for 1965 and 1974 were each derived by combining answers to questions which assessed the usual frequency of drinking and amount consumed each week of wine, beer, and spirits, and then converting the information into the total number of drinks per month. The scores were grouped into abstainers (zero drinks/month), light drinkers (1-30 drinks/month for women and 1-45 drinks/month for men), and moderate drinkers ( $\geqslant 31$ drinks/month for women and $\geqslant 46$ drinks/month for men). ${ }^{22}$ About $18 \%$ of the respondents were moderate drinkers.

For each sex nine categories of change in alcohol consumption were defined by using the 1965 and 1974 alcohol scores (see table I). Cox's proportional hazard model ${ }^{23}$ was used to examine the associations between these categories of change in alcohol consumption and subsequent mortality at 11 years from all causes and from ischaemic heart disease. Preliminary analyses were done using all nine categories. Because there were no deaths and very small numbers of people at risk in two of the categories we condensed the nine categories into seven, as shown in table II.

In the initial analyses the categories of change in alcohol consumption were represented by indicator variables with the light/light category serving as the reference. Age in 1965 was included in all models as a continuous variable. The antilogarithms of the regression coefficients of the indicator variables estimate the relative hazards or approximate instantaneous relative risks, which compare each category of change with those who were light drinkers in 1965 and 1974.

Based on the results of the initial models we further condensed the seven categories of change into three new categories: those who gave up drinking, those who continued to drink, and those who were long term abstainers. People who gave up drinking were defined as those who reported consumption of alcohol in any amount in 1965 and no alcohol consumption in 1974. Continuing drinkers were those who reported any amount of consumption in 1974; this category includes the small number of people who either resumed or started drinking after 1965 . Long term abstainers were defined as those reporting no alcohol consumption in both 1965 and 1974. Indicator variables were created for those who gave up drinking and abstainers with continuing drinkers serving as the reference category.

We analysed the age adjusted relative hazards of mortality from all causes and from ischaemic heart disease in those who gave up drinking and abstainers compared with continuing drinkers, with and without adjustment for a series of psychosocial and health behavioural covariables and chronic conditions and symptoms reported in 1965 and 1974 that might confound the relation. Health conditions and symptoms

TABLE I - Distribution of respondents according to alcohol consumption in 1974 and number of deaths from all causes and ischaemic heart disease, all by alcohol consumption in 1965

\begin{tabular}{|c|c|c|c|c|c|c|c|c|c|c|c|c|}
\hline \multirow[b]{2}{*}{$\begin{array}{l}\text { Alcohol consumption in } 1965 \\
\text { (drinks/month) }\end{array}$} & \multicolumn{3}{|c|}{ None } & \multicolumn{3}{|c|}{ Light } & \multicolumn{3}{|c|}{ Moderate } & \multicolumn{3}{|c|}{ Total } \\
\hline & $\begin{array}{l}\text { No of } \\
\text { respondents }\end{array}$ & All causes & $\begin{array}{l}\text { Ischaemic } \\
\text { heart disease }\end{array}$ & $\begin{array}{l}\text { No of } \\
\text { respondents }\end{array}$ & All causes & $\begin{array}{l}\text { Ischaemic } \\
\text { heart disease }\end{array}$ & $\begin{array}{l}\text { No of } \\
\text { respondents }\end{array}$ & All causes & $\begin{array}{l}\text { Ischaemic } \\
\text { heart disease }\end{array}$ & $\begin{array}{l}\text { No of } \\
\text { respondents }\end{array}$ & All causes & $\begin{array}{c}\text { Ischaemic } \\
\text { heart disease }\end{array}$ \\
\hline \multicolumn{13}{|c|}{ Women $(n=2225)$} \\
\hline None & 436 & 86 & 27 & 129 & 18 & 7 & 7 & 1 & & 572 & 105 & 34 \\
\hline Light $(1-30)$ & 157 & 28 & 13 & 1001 & 114 & 34 & 175 & 13 & 3 & 1333 & 155 & 50 \\
\hline Moderate $(\geqslant 31)$ & 10 & 4 & 2 & 108 & 13 & 3 & 202 & 14 & 3 & 320 & 31 & 8 \\
\hline Total & 603 & 118 & 42 & 1238 & 145 & 44 & 384 & 28 & 6 & 2225 & 291 & 92 \\
\hline \multicolumn{13}{|c|}{$\operatorname{Men}(n=1845)$} \\
\hline None & 175 & 47 & 15 & 73 & 9 & 6 & 10 & 1 & & 258 & 57 & 21 \\
\hline Light $(1-45)$ & 104 & 33 & 7 & 876 & 129 & 49 & 206 & 24 & 5 & 1186 & 186 & 61 \\
\hline Moderate $(\geqslant 46)$ & 21 & 4 & 0 & 136 & 23 & 6 & 244 & 30 & 7 & 401 & 57 & 13 \\
\hline Total & 300 & 84 & 22 & 1085 & 161 & 61 & 460 & 55 & 12 & 1845 & 300 & 95 \\
\hline
\end{tabular}


TABLE II-Age adjusted association between change in alcohol consumption and mortality from all causes and ischaemic heart disease. Figures are relative risks ( $95 \%$ confidence intervals)

\begin{tabular}{|c|c|c|}
\hline $\begin{array}{l}\text { Changes in alcohol } \\
\text { consumption (1965-74) }\end{array}$ & $\begin{array}{c}\text { Women } \\
(\mathbf{n}=2225)\end{array}$ & $\underset{(n=1845)}{M e n}$ \\
\hline \multicolumn{3}{|c|}{ All causes } \\
\hline None/none & $1.00(0.75$ to 1.33$)$ & $1.28(0.90$ to 1.81$)$ \\
\hline None/light and moderate & $1 \cdot 15(0.71$ to 1.87$)$ & $0.72(0.38$ to 1.38$)$ \\
\hline Light/moderate & $0.85(0.48$ to 1.51$)$ & $1.00(0.66$ to 1.51$)$ \\
\hline Light/light (reference) & $1 \cdot 00$ & $1 \cdot 00$ \\
\hline Moderate/moderate & $0.88(0.51$ to 1.55$)$ & $1.01(0.72$ to 1.44$)$ \\
\hline Moderate/light & $1 \cdot 15(0.65$ to 2.05$)$ & $1.31(0.86$ to 2.00$)$ \\
\hline Light and moderate/none & $1.47(0.99$ to $2 \cdot 17)$ & $1.46(1.00$ to $2 \cdot 13)$ \\
\hline \multicolumn{3}{|c|}{ Ischaemic heart disease } \\
\hline None/none & $0.92(0.55$ to 1.55$)$ & $1 \cdot 16(0.63$ to $2 \cdot 14)$ \\
\hline None/light and moderate & $1.33(0.59$ to 3.01$)$ & $1.25(0.53$ to 2.97$)$ \\
\hline Light/moderate & $0.66(0.20$ to $2 \cdot 14)$ & $0.76(0.35$ to 1.65$)$ \\
\hline Light/light (reference) & 1.00 & $1 \cdot 00$ \\
\hline Moderate/moderate & $0.71(0.22$ to $2 \cdot 34)$ & $0.72(0.37$ to 1.40$)$ \\
\hline Moderate/light & $0.94(0.29$ to 3.07$)$ & $1.62(0.84$ to 3.11$)$ \\
\hline Light and moderate/none & $2 \cdot 29(1.25$ to $4 \cdot 20)$ & $0.78(0.35$ to 1.77$)$ \\
\hline
\end{tabular}

reported in 1965 and 1974 were categorised as present in 1965, not present in 1965 but present in 1974, and not present in either 1965 or 1974 . Each variable was represented in a model by two indicator variables representing the first two categories referenced in the third category.

\section{Results}

Table I presents the distribution of the change in alcohol consumption. The largest percentages of respondents $(45.0 \%$ of women and $47.5 \%$ of men) were light drinkers both in 1965 and 1974. The percentage of women reporting no alcohol consumption in both 1965 and 1974 (long term abstainers) was twice as high as that for men $(19.6 \%$ compared with $9 \cdot 5 \%)$. In all, $7 \cdot 5 \%$ of women and $6 \cdot 8 \%$ of men gave up drinking. Of the 603 women who were non-drinkers in 1974, 436 (72.3\%) reported long term abstention as compared with 175 out of $300(58 \cdot 3 \%)$ men.

In the preliminary analyses using the nine categories of change in consumption of alcohol mortality from all causes in women was substantially raised in moderate drinkers who gave up drinking between 1965 and 1974 (relative risk $6.56,95 \%$ confidence interval 0.41 to 17.84). Women who were light drinkers and who gave up drinking had a relative risk of 1.32 but the $95 \%$ confidence interval was broad $(0 \cdot 87$ to $2 \cdot 00)$. Women

TABLE III-Association between non-drinking subgroup and death from all causes and ischaemic heart disease (1974-84) adjusted for age and other covariables. Figures are relative risks (95\% confidence intervals)

\begin{tabular}{|c|c|c|c|c|}
\hline \multirow[b]{2}{*}{ Covariable } & \multicolumn{2}{|c|}{$\begin{array}{c}\text { Women } \\
(\mathrm{n}=1802)\end{array}$} & \multicolumn{2}{|c|}{$\begin{array}{c}\text { Men } \\
(\mathrm{n}=1582)\end{array}$} \\
\hline & $\begin{array}{l}\text { Former } \\
\text { drinkers }\end{array}$ & Abstainers & $\begin{array}{l}\text { Former } \\
\text { drinkers }\end{array}$ & Abstainers \\
\hline & & All causes ${ }^{\star}$ & & \\
\hline Age alone & $1 \cdot 72(1 \cdot 11$ to $2 \cdot 66)$ & $1.07(0.77$ to 1.47$)$ & $1.32(0.87$ to 2.01$)$ & $1.40(0.98$ to $2 \cdot 00)$ \\
\hline C hronic conditionsł & $1.61(1.02$ to 2.53$)$ & $0.92(0.66$ to 1.30$)$ & $0.99(0.62$ to 1.57$)$ & $1.39(0.96$ to 2.01$)$ \\
\hline Race & $1.70(1 \cdot 10$ to $2 \cdot 63)$ & $1.03(0.74$ to 1.43$)$ & $1.30(0.85$ to 2.00$)$ & $1.38(0.96$ to 2.00$)$ \\
\hline Education level & $1.75(1.13$ to 2.72$)$ & $1.08(0.78$ to 1.50$)$ & $1.1(0.78$ to 1.82$)$ & $1.35(0.94$ to 1.93$)$ \\
\hline Income & $1.70(1.09$ to 2.64$)$ & $1.05(0.76$ to 1.46$)$ & $1.21(0.79$ to 1.86$)$ & $1.36(0.95$ to 1.94$)$ \\
\hline Physical activity & $1.70(1.10$ to $2 \cdot 63)$ & $1.06(0.76$ to 1.46$)$ & $1.26(0.82$ to 1.92$)$ & $1.38(0.97$ to 1.98$)$ \\
\hline Smoking status & $1.80(1.16$ to 2.79$)$ & $1.14(0.82$ to 1.58$)$ & $1.34(0.88$ to 2.03$)$ & $1.48(1.03$ to $2 \cdot 12)$ \\
\hline Social network index & $1.69(1.09$ to 2.61$)$ & $1.06(0.77$ to 1.47$)$ & $1.27(0.84$ to 1.94$)$ & $1.44(1.01$ to 2.06$)$ \\
\hline Depression & $1.63(1.05$ to 2.52$)$ & $1.04(0.75$ to 1.44$)$ & $1.27(0.83$ to 1.94$)$ & $1.39(0.97$ to 1.98$)$ \\
\hline Perceived health & $1.51(0.98$ to 2.34$)$ & $0.97(0.70$ to 1.34$)$ & $1.14(0.74$ to 1.75$)$ & $1.32(0.92$ to 1.89$)$ \\
\hline \multicolumn{5}{|c|}{ Ischaemic heart diseaset } \\
\hline Age alone & $2.75(1.44$ to 5.23$)$ & $0.78(0.42$ to 1.45$)$ & $0.95(0.41$ to 2.20$)$ & $1.40(0.76$ to 2.58$)$ \\
\hline Chronic conditionsł & $2 \cdot 27(1 \cdot 14$ to 4.54$)$ & $0.66(0.34$ to 1.26$)$ & $0.71(0.28$ to 1.75$)$ & $1.51(0.80$ to 2.85$)$ \\
\hline Race & $2 \cdot 70(1.42$ to $5 \cdot 14)$ & $0.72(0.38$ to 1.34$)$ & $1.01(0.43$ to $2 \cdot 37)$ & $1.49(0.80$ to 2.80$)$ \\
\hline Education level & $2.79(1.46$ to 5.35$)$ & $0.79(0.42$ to 1.47$)$ & $0.81(0.35$ to 1.90$)$ & $1.30(0.70$ to 2.41$)$ \\
\hline Income & $2.76(1.43$ to 5.31$)$ & $0.76(0.41$ to 1.43$)$ & $0.93(0.40$ to $2 \cdot 18)$ & $1.35(0.73$ to 2.50$)$ \\
\hline Physical activity & $2.74(1.44$ to 5.23$)$ & $0.78(0.42$ to 1.45$)$ & $0.91(0.39$ to $2 \cdot 13)$ & $1.39(0.75$ to 2.56$)$ \\
\hline Smoking status & $3.03(1.59$ to 5.79$)$ & $0.88(0.47$ to 1.66$)$ & $0.96(0.41$ to 2.23$)$ & $1.48(0.80$ to $2 \cdot 74)$ \\
\hline Social network index & $2.66(1.40$ to 5.06$)$ & $0.77(0.41$ to 1.43$)$ & $0.93(0.40$ to 2.15$)$ & $1.42(0.77$ to 2.63$)$ \\
\hline Depression & $2.60(1.36$ to 4.97$)$ & $0.76(0.41$ to 1.42$)$ & $0.97(0.42$ to $2 \cdot 26)$ & $1.41(0.77$ to 2.60$)$ \\
\hline Perceived health & $2.35(1.23$ to 4.50$)$ & $0.70(0.38$ to 1.30$)$ & $0.86(0.36$ to $2 \cdot 01)$ & $1.33(0.72$ to 2.47$)$ \\
\hline
\end{tabular}

^No of deaths $=212$ women, $237 \mathrm{men}$.

†No of deaths $=67$ women, 76 men.

†High blood pressure, heart trouble, stroke, chest pain, trouble breathing, bronchitis, diabetes, cancer, ulcer, and liver trouble. Categorised as (1) present in 1965 and (2) not present in 1964 but present in 1974 referenced against (3) not present in 1965 or 1974. who were light or moderate drinkers who gave up also had increased risks of death from ischaemic heart disease (relative risk 2.04, 1.08 to 3.87 for light drinkers and $10.45,2.49$ to 43.83 for moderate drinkers). Consistent abstainers were not different from the reference group, with relative hazards near 1.0 for mortality from all causes and from ischaemic heart disease $(0.99,0.74$ to 1.33 for all causes and 0.92 , 0.54 to 1.55 for ischaemic heart disease). Among men mortality from all causes was raised in light drinkers who gave up drinking $(1 \cdot 47,0.98$ to $2 \cdot 20)$. Moderate drinkers who gave up had a similar rise in risk but the confidence interval was unacceptably wide $(1.41,0.62$ to 3.21$)$. Male abstainers had a relative risk of 1.28 $(0.90$ to 1.81$)$. For mortality from ischaemic heart disease in men, none of the categories showed significantly higher or lower risk compared with light/light drinkers.

Table II shows the results of combining the two categories of light and moderate drinkers who gave up drinking and the two categories of people who started drinking. For both men and women mortality from all causes was raised in those who gave up drinking compared with the light/light reference category (relative risk $1 \cdot 47,95 \%$ confidence interval 0.99 to $2 \cdot 17$ for women and $1.46,1.00$ to 2.13 for men). Women who gave up drinking also had a substantially raised risk of ischaemic heart disease $(2 \cdot 29,1 \cdot 25$ to $4 \cdot 20)$. For men none of the groups had a reliably estimated increased risk of ischaemic heart disease.

Table III shows the association between the nondrinking subgroup (former drinkers and lifetime abstainers), and mortality from all causes and from ischaemic heart disease adjusted for several covariates. The reference category for those who gave up drinking and abstainers was those who reported any drinking in 1974. The numbers of women and men analysed were smaller because some respondents had missing values for one or more of the adjustment variables. Women who had given up drinking had a relative risk of mortality from all causes of 1.72 (1.11 to 2.66) compared with drinkers. Because a decline in health status might lead to a decline in or abstention from alcohol consumption, we studied a model which included a set of health conditions and symptoms recorded in 1965 and 1974 that are associated with mortality from either all causes or ischaemic heart disease. Adjusting for 10 chronic conditions and symptoms had little effect on the raised risk of death from all causes in women who had given up drinking. With the possible exception of perceived health $(1.51$, 0.98 to $2 \cdot 34$ ), none of the psychosocial and health behavioural covariables including race, education, income, physical activity, smoking, social network index, and depression substantially altered the association for death from all causes. On the other hand, the positive association between giving up drinking and mortality from ischaemic heart disease declined a little when adjusted for chronic conditions (from $2 \cdot 75,1 \cdot 44$ to $5 \cdot 23$, to $2.27,1.14$ to 4.54 ). Of the remaining covariables, only perceived health substantially altered the association for mortality from ischaemic heart disease. The relative risk was reduced from $2.75(1.44$ to 5.23$)$ to $2.35(1.23$ to 4.50$)$. No association was found between abstaining from drink and mortality from all causes or ischaemic heart disease for women.

Among men, when those who gave up drinking were compared with drinkers the relative risk of mortality from all causes was $1.32(0.87$ to $2 \cdot 01)$. Adjusting for chronic conditions reduced the relative risk to 0.99 $(0.62$ to 1.57$)$. Adjustment for perceived health also resulted in a decrease in the relative risk to near 1.0 . There was no association between giving up drinking and mortality from ischaemic heart disease for men. The risks of death from all causes and from ischaemic 
heart disease were raised for abstainers compared with drinkers $(1.40,0.98$ to 2.00 , and $1.40,0.76$ to 2.58 , respectively), although neither estimate was significant. Neither adjusting for health status nor adjusting for psychosocial covariables substantially altered the relative risk.

\section{Discussion}

Our results provide further evidence that nondrinkers are a heterogeneous group of people who may have different risks of death depending on the length of their abstention from drinking alcohol. The risk in women who had given up drinking in the previous nine years was higher than the risk in women who had continued to drink. A similar increase in risk was not seen in men who had given up drinking. On the other hand, long term male abstainers were at a marginally increased risk of death compared with drinkers. The same increase in risk was not found in female abstainers.

There are several features of the measurement of alcohol consumption which need comment. Although our measure takes into account amount and frequency of consumption of alcoholic beverages in a usual week, it does not allow for the amount of ethanol consumed to be measured nor does it take into account the type of beverage consumed (beer, wine, or liquor) or the style of timing the consumption. We also do not know when in the nine year period the pattern of alcohol consumption changed.

While studying change in alcohol consumption over time has many features to recommend it over studies which look at consumption only at one point in time, it has unique problems. Because of the long period over which we assessed changes in consumption some of the features of the relation between consumption patterns and risk of death may be obscured. For example, the relatively small impact of health conditions may be due to the fact that only people who survived for nine years are included in the analyses.

Despite this, and the small numbers of deaths in several of the categories, several conclusions can be drawn from these analyses. The increased risk in nondrinkers relative to drinkers depends on the subgroup of non-drinkers being considered and on sex. For men the apparent increased risk of death from all causes in those who gave up drinking compared with those who continued to drink seems to be related to the presence of chronic conditions and symptoms associated with giving up. Male abstainers were at slightly increased risk of death from all causes and from ischaemic heart disease compared with drinkers, and this increase was not related to the presence of chronic illness. Compared with continuing drinkers, women who gave up drinking were at substantially increased risk. This increased risk is not completely explained by health status or other confounders. The reasons for this sex difference in the impact of giving up drinking are not apparent and suggest that sex specific analyses are to be preferred.

The problem of heterogeneity of alcohol consumption categories also applies to the group of light to moderate drinkers. Occasional drinkers (less than one drink a day) are sometimes classified with non-drinkers and at other times included in the light to moderate drinking group, which is the group sometimes found to have a lower risk of death. Future studies of the association of alcohol consumption and mortality should look separately at very light and light to moderate drinkers.

Many studies have concluded that light to moderate drinking provides a "protective" effect, ${ }^{24}$ but the heterogeneity of the non-drinking group suggests caution when making public health recommendations. Increased attention to the natural course of alcohol consumption may clarify whether light to moderate drinking is protective.

The study was supported in part by a grant from the National Institute on Aging.

1 Yano K, Reed DM, McGee DL. Ten-year incidence of coronary heart disease in the Honolulu heart program. Am $\mathcal{F}$ Epidemiol 1984;119:653-66.

2 Yano K, Rhoads GG, Kagan A. Coffee, alcohol and risk of coronary heart disease among Japanese men living in Hawaii. $N$ Engl f Med 1977;297: $405-9$.

3 Moore RD, Pearson TA. Moderate alcohol consumption and coronary artery disease: a review. Medicine 1986;65:242-67.

4 Dyer AR, Stamler J, Paul O, Lepper M, Shekelle RB, McKean H, et al. Alcohol consumption and 17-year mortality in the Chicago Western Electric Company study. Prev Med 1980;9:78-90.

5 Klatsky AL, Friedman GD, Siegelaub AB. Alcohol consumption before myocardial infarction. Ann Intern Med 1974;81:294-301.

6 Marmot MG, Shipley MJ, Rose G, Thomas BJ. Alcohol and mortality: a U-shaped curve. Lancet 1981;i:580-3.

7 Boffetta P, Garfinkel L. Alcohol drinking and mortality among men enrolled in an American Cancer Society prospective study. Epidemiol 1990;1:342-8.

8 Stampfer MJ, Colditz GA, Willett WC, Speizer FE, Hennekens CH. A prospective study of moderate alcohol consumption and the risk of coronary disease and stroke in women. $N$ Engl f Med 1988;319:267-73.

9 Castelli WP, Gordon T, Hiortland MC, Kagan A, Doyle JT, Hames CG, et al. Alcohol and blood lipids. The cooperative lipoprotein phenotyping study. Lancet 1977;ii: 153-5.

10 Ernst N, Fisher M, Smith W, Gordon T, Rifkind BM, Little JA, et al. The association of plasma high density lipoprotein cholesterol with dietary intake and alcohol consumption. The Lipid Research Clinics program prevalence study. Circulation 1980;62(suppl 4):41-52.

11 Criqui MH. Alcohol and cardiovascular mortality. In: Kaplan RM, Criqui $\mathrm{MH}$, eds. Behavioral epidemiology and disease prevention. New York: Plenum Press, 1985:67-90.

12 Meade TW, Chakrabarti R, Haines AP, North WRS, Stirling Y. Characteristics affecting fibrinolytic activity and plasma fibrinogen concentrations. BMF 1979;i:153-6.

13 Camacho TC, Kaplan GA, Cohen RD. Alcohol consumption and mortality in Alameda County. $\mathcal{F}$ Chronic Dis 1987;40:229-36.

14 Colsher PL, Wallace RB. Is modest alcohol consumption better than none at all? In: Breslow L, ed. Annual Review of Public Health. Vol 10. Palo Alto, all? In: Breslow L, ed. Annual Reriew

14a Jackson R, Scragg R, Beaglehole R. Alcohol consumption and risk of coronary heart disease. BMF 1991;303:211-6.

15 Dyer AR, Stamler J, Paul O, Berkson DM, Lepper MH, McKean H, et al. Alcohol consumption, cardiovascular risk factors, and mortality in two Chicago epidemiologic studies. Circulation 1977;56:1067-74.

16 US Department of Health, Education and Welfare. Second special report to the US Congress on alcohol and health from the Secretary of Health, Education and Welfare. Preprint edition. Washington, DC: DHEW, 1974.

17 Wannamethee G, Shaper AG. Men who do not drink: a report from the British regional heart study. Int $\mathcal{F}$ Epidemiol 1988;17:307-16.

18 Berkman LF, Breslow L. Health and ways of living: the Alameda County study. New York: Oxford University Press, 1983.

19 Belloc NB, Arellano MG. Computer record linkage on a survey population. Health Serv Rep 1973;88:344-50.

20 Arellano MG, Petersen GR, Pettiti DB, Smith RE. The California Automated Mortality Linkage System (CAMLIS). Am f Public Health 1984;74: 1324-30.

21 Seeman TE, Kaplan GA, Knudsen L, Cohen R, Guralnik J. Social network ties and mortality among the elderly in the Alameda County study. Am f Epidemiol 1987;126:714-23.

22 Frezza M, Di Padova C, Pozzato G, Terpin M, Baraona E, Lieber CS, et al. High blood alcohol levels in women. N Engl I Med 1990;322:95-9.

23 Kalbfleisch JD, Prentice RL. The statistical analysis of failure time data. New York: John Wiley, 1980

24 Ellison RC. Cheers [editorial]. Epidemiol 1990;1:337-9.

(Accepted 23 fuly 1991) 